DOI: 10.5604/01.3001.0012.0715

\title{
A COMPARISON STUDY OF THE FEATURES OF DC/DC SYSTEMS WITH SI IGBT AND SIC MOSFET TRANSISTORS
}

\author{
Karol Fatyga, Lukasz Kwaśny, Bartlomiej Stefańczak \\ Lublin University of Technology, Faculty of Electrical Engineering and Computer Science, Department of Electrical Drives and Machines
}

Abstract. This paper presents a comparison of the efficiency of two bidirectional DC/DC converters based on dual H-bridge topology. Tested converters were built using Si-based IGBT transistors and SiC-based MOSFETs. The results of the research are efficiency characteristics, taken from tests

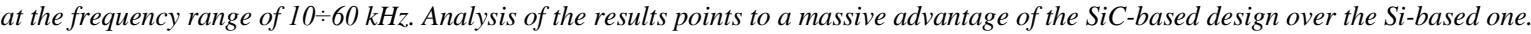

Keywords: IGBT, SiC, Transistor, MOSFET, DC/DC converter

\section{BADANIA PORÓWNAWCZE SPRAWNOŚCI UKLADÓW DC/DC Z TRANZYSTORAMI SI IGBT ORAZ TRANZYSTORAMI SIC TYPU MOSFET}

\begin{abstract}
Streszczenie. W artykule zaprezentowano badania porównawcze sprawności dwóch dwukierunkowych przeksztaltników DC/DC wykonanych w topologii podwójnego mostka $H$. Badane przeksztaltniki wykonano $w$ technologii krzemowej z tranzystorami IGBT oraz $w$ technologii węglika krzemu z tranzystorami SiC MOSFET. Rezultatem badań sa charakterystyki sprawności uzyskane z testów przy częstotliwości pracy w zakresie 10 $\div 60$ kHz. Analiza uzyskanych wyników wskazuje na zdecydowana przewage rozwiazania wykonanego $w$ technologii węlika krzemu nad rozwiazaniem z tranzystorami krzemowymi IGBT.
\end{abstract}

Słowa kluczowe: IGBT, SiC, Tranzystor, MOSFET, przekształtnik DC/DC

\section{Introduction}

Technological advancements, government actions and developer initiatives the during last few years resulted both in a massive boom in technology and an intensive interest in emobility. Both contact and contactless charging technologies are being developed or improved, along with more efficient energy storage devices. Advancements in semiconductor technology also help in developing new solutions in terms of energy supply and electric drives.

One of the most significant factors impeding development of e-mobility is the lack or shortage of electric vehicle charging infrastructure. Charging the vehicle, according to IEC-62196-1, assumes that galvanic isolation between the utility grid and an electric vehicle will be provided by using isolating elements. Using a grid-frequency transformer in a device with output power rated at $50 \mathrm{~kW}$ (fast-charging device) [2], will drastically increase both the size and production cost of the charging system. Because of this, high-frequency transformers are used and entire devices are built around them, creating high-frequency isolated DC/DC converters, which work in conjunction with AC/DC converters to deliver power to electric vehicle (Fig. 1) [4].

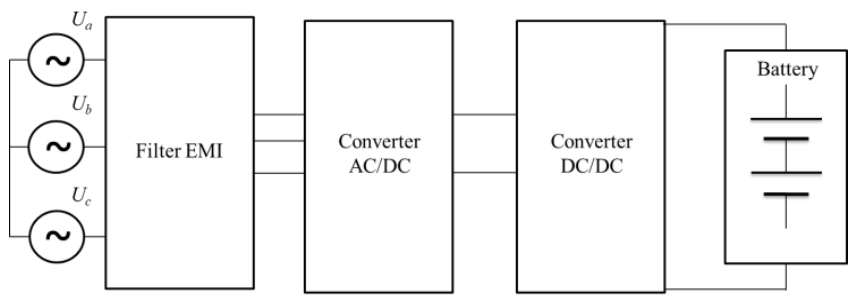

Fig. 1. Block diagram of the charging system

In isolated DC/DC converter systems, several different topologies are used, consisting of two to eight transistor switches [6], where eight-switch systems, so called dual active bridges (Fig. 2) [1] can achieve the highest power density and allow soft switching to be implemented into the system, further increasing its efficiency [7].

Systems using such topology also allow energy flow in both directions, which enables the use of an electric vehicle's battery as distributed energy storage, assuming that there are enough electric vehicles connected to chargers at any given time [3].

Using modern Silicon Carbide based semiconductors allows a further decrease in the size of DC/DC converters. This is caused by a wider bandgap, allowing transistor operation in higher frequency ranges. Since the frequency is increased, less magnetic materials and smaller capacitors are required for their proper operation. This reduces both the size and the cost of a DC/DC converter.

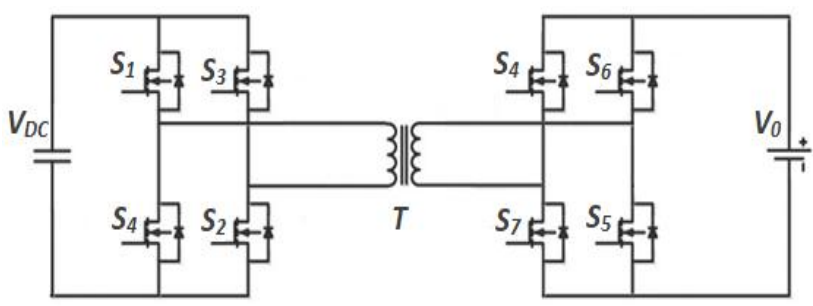

Fig. 2. Scheme of a DC/DC bidirectional converter

Using $\mathrm{SiC}$ semiconductor technology in fast charging systems is relatively new, because only for a few years have transistors been available that can withstand currents ranging from tens to hundreds of Amperes, while at the same time keeping high isolation voltage. Of course, since those devices are cutting-edge technology, their price is higher than IGBT Silicon semiconductors, and because of limited availability of $\mathrm{SiC}$ semiconductors, IGBTs will still be used for a long time before they get obsolete.

When choosing semiconductor technology for DC/DC converters it is important to know about the efficiency of both the technologies discussed. This paper presents their comparative laboratory tests. It consists of an introductory part, describing the topology and control scheme of the converter tested. Next, the main parameters of the tested converters are presented. The test results, their evaluation and analysis make the final and most important part, concluding the paper and suggesting an answer to the problem contained in the title.

\section{Analysis of the operation of a DC/DC converter}

To depict the operation of a bidirectional DC/DC converter, each conducting cycle are shown in Figure 3. Transistor driving signals as well as transformer voltage and current waveforms are presented in Figure 4. For clarity of discussion, the control scheme selection debate is skipped, and the paper is focusing on the efficiency of SiC-based and Si-based DC/DC converters.

High frequency DC/DC converters are usually frequency controlled or phase controlled, with a trend to implement switching transistors during a zero current period. This allows to achieve very high efficiency. The prototype laboratory system was 
phase-controlled: the H-bridge driving the primary side was the active control element, while the H-bridge on the secondary side was used passively: transistor switches were all driven low, and only the diodes from the transistor modules were used as a passive Graetz rectifier (Fig. 3).

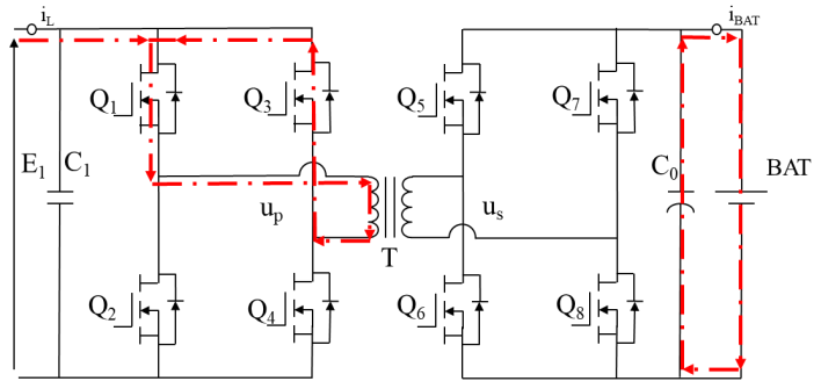

STAGE 1

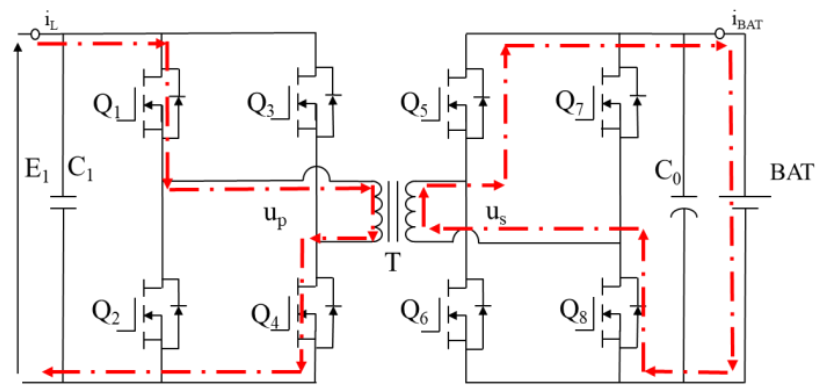

STAGE 2

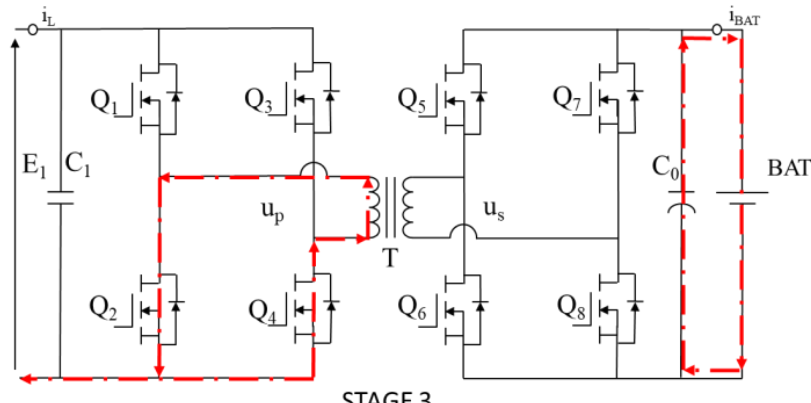

STAGE 3

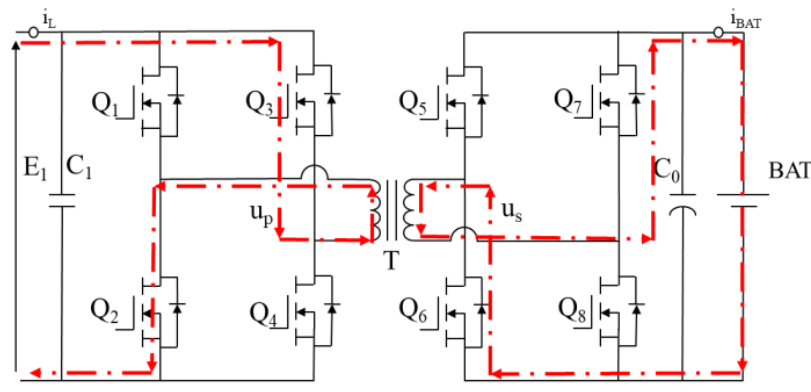

STAGE 4

Fig. 3. Current flow through the transformer in subsequent stages of the operation

On the primary side, the H-bridge can be divided into a left half-bridge and a right half-bridge. The left half-bridge is responsible for shutting the energy transfer window, while the right one is responsible for opening it. Transistors in one halfbridge are driven with $50 \%$ fixed width pulse. The right halfbridge driving signals are phase-shifted in relation to the left halfbridge. At the first stage of the operation the transformer is connected to DC bus + through the Q1 and Q3 switches. At the second stage, the current flows through switch Q1, the transformer's primary winding, and switch Q4. During this stage the voltage across the transformer is $+\mathrm{V}_{\mathrm{DC}}$. In stage three the transformer is connected through the Q2 and Q4 switches to DC bus -. In stage 4 the current flows through Q3, the transformer's primary winding, and Q2. During this stage the voltage across the transformer is $-\mathrm{V}_{\mathrm{DC}}$. The current in stages two and four flows through the transformer's windings in opposite directions, creating an alternating high frequency current. By changing the phase-shift between the left and right half-bridge, it is possible to lengthen or shorten the transfer window, and therefore control how much energy is transferred through the transformer. The transistor driving signals, primary winding voltage and the current are presented in Figure 4.
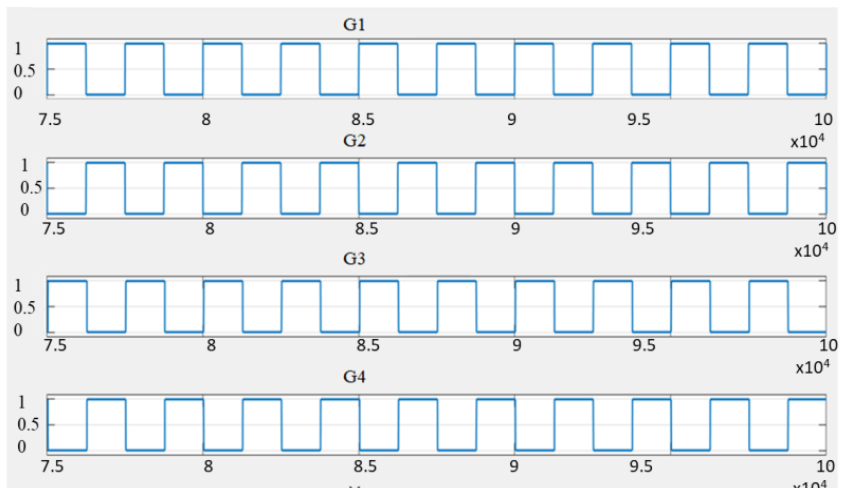

$\mathrm{V}_{\text {prim }}$

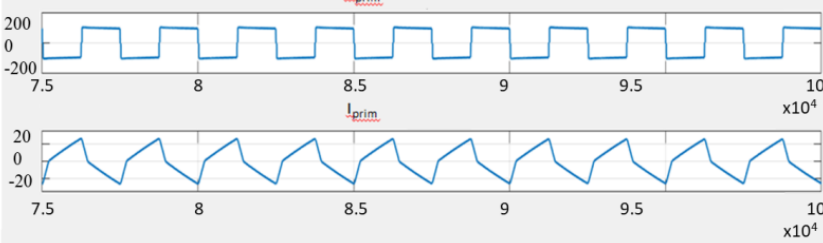

Fig. 4. Phase control of transistor inverters with voltage and current diagrams $V_{\text {prim }}$ and $I_{\text {prim }}$

\section{Prototype test systems}

Laboratory tests were performed on DC/DC converters built on two types of transistors. One DC/DC converter was built on bipolar transistors with isolated gate (IGBT), using silicon semiconductors. The other DC/DC converter was based on Silicon Carbide MOSFET (Metal-Oxide Semiconductor Field-Effect Transistor) semiconductors. Two test systems were built, based on the structure presented in Figure 5.

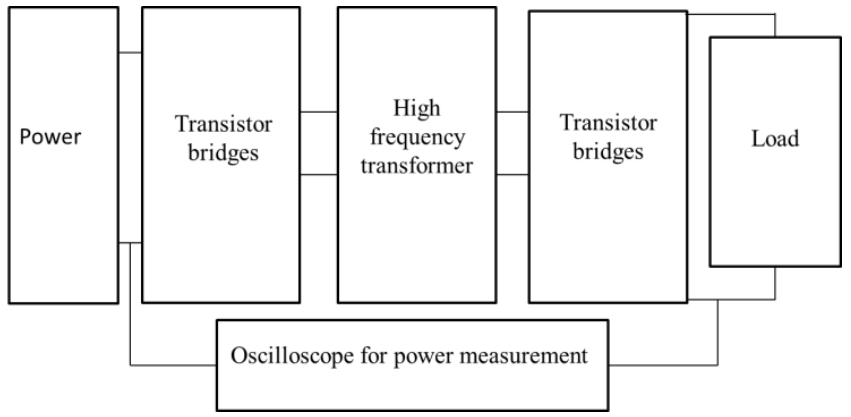

Fig. 5. Block diagram of the power measurement system

To perform tests with the IGBT-based converter, Mitsubishi CM200DX-24S modules were used. A single module consists of 2 transistors and can be used as a half-bridge. These modules have been in production since 2013. Their parameters are as follows: rated collector current $I_{\mathrm{c}}=200 \mathrm{~A}$, collector-emitter voltage $V_{\text {ces }}=1200 \mathrm{~V}$ and maximum junction operating temperature $T_{\text {jmax }}=175^{\circ} \mathrm{C}$. According to the datasheet, the collector-emitter voltage drop is $2.25 \mathrm{~V}$ maximum. This defines power losses of $450 \mathrm{~W}$ while operating under maximum load. In the IGBT-based DC/DC converter, a single-phase transformer was used, with the rated power of $P_{\mathrm{Z}}=30 \mathrm{kVA}$ and the switching frequency of $f_{\mathrm{z}}=25 \mathrm{kHz}$. The system is depicted in Figure 6 . 


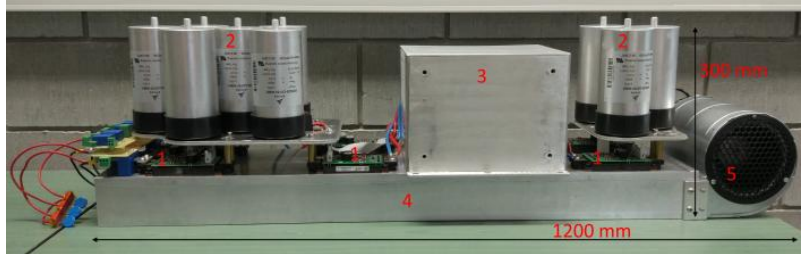

Fig. 6. Measurement system built of IGBT silicon transistors: 1 - transistors, 2 - condensers, 3 -transformer, 4 - heatsink, 5 -fan

Another type of transistor used for DC/DC converters was the Silicon Carbide based MOSFET transistor. For laboratory tests, Infineon FF11MR12W1M1_B11 transistors were used. These were introduced to the market in 2017. Their parameters: drainsource voltage $V_{\mathrm{DDS}}=1200 \mathrm{~V}$, drain current $I_{\mathrm{D}}=100 \mathrm{~A}$, operating temperature $T_{\mathrm{v}}=150^{\circ} \mathrm{C}$ and drain-source junction resistance $R_{\mathrm{DS}}=11 \mathrm{~m} \Omega$. To provide galvanic isolation a single-phase transformer was used, with the output power of $20 \mathrm{kVA}$ and the nominal frequency of $100 \mathrm{kHz}$. The prototype is depicted in Figure 7

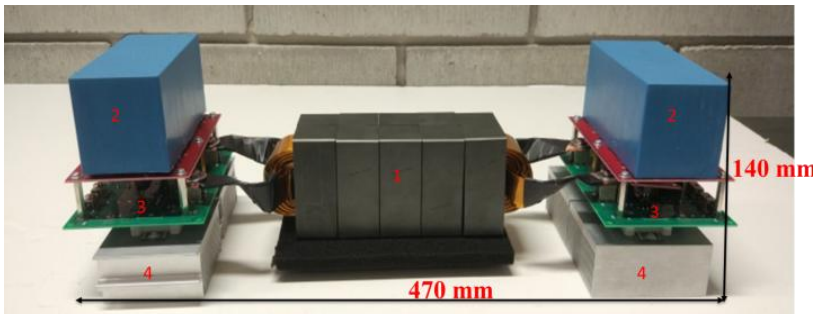

Fig. 7. Test system built of MOSFET SiC transistors: 1 - transformer, 2 - capacitors, 3 - transistor bridge, 4 - radiators

An important parameter during DC/DC converter efficiency testing are transistor switching losses. According to the datasheet, an IGBT transistor requires $30.07 \mathrm{~mJ}$ of energy to turn it on, and $21.5 \mathrm{~mJ}$ to turn it off. For comparison, SiC MOSFET requires $1.4 \mathrm{~mJ}$ to create a conduction channel, and $0.645 \mathrm{~mJ}$ to shut it down.

\section{Analysis of the results}

In order to perform results tests in as wide a frequency range as possible, and at the same time ensure safety of the equipment, the supply voltage for both systems was dropped to $165 \mathrm{~V}$. The transformer's primary current was controlled by the controlling phase in the primary side H-bridge. Tests were performed for four different transistor switching frequencies: $10 \mathrm{kHz}$ (Fig. 8), $20 \mathrm{kHz}$ (Fig. 9), $40 \mathrm{kHz}$ (Fig. 10) and $60 \mathrm{kHz}$ (Fig. 11).

The characteristics were derived on the basis of measurements with a Yokogawa PX8000 oscilloscope.

It is clearly noticeable from the presented characteristics that $\mathrm{SiC}$ MOSFET based converters have a higher efficiency for every switching frequency. The IGBT-based converter achieved its peak efficiency at $10 \mathrm{kHz}$ switching frequency, while the SiC MOSFET based converter achieved 95.87 efficiency at $20 \mathrm{kHz}$. Another matter is the shape of the characteristics: for smaller loads IGBTbased converter efficiency drops significantly. This effect is not so severe for the SiC MOSFET based design.

The reason for this are the switching losses. The cost of elements used for both devices needs to be taken into consideration. The cost of the IGBT transistor based design is significantly higher than the SiC MOSFET design. Despite using cheaper switches, well established on the semiconductor market, the cost of magnetic elements, additional capacitors or a massive radiator, which can dissipate power losses that turn into heat from transistors, makes the IGBT design more expensive than the SiC MOSFET system, which uses transistors that are a few times more expensive. Another matter is the size of the device. The SiC-based system is less than half the size of the IGBT-based system. The size difference is presented in Figure 12.

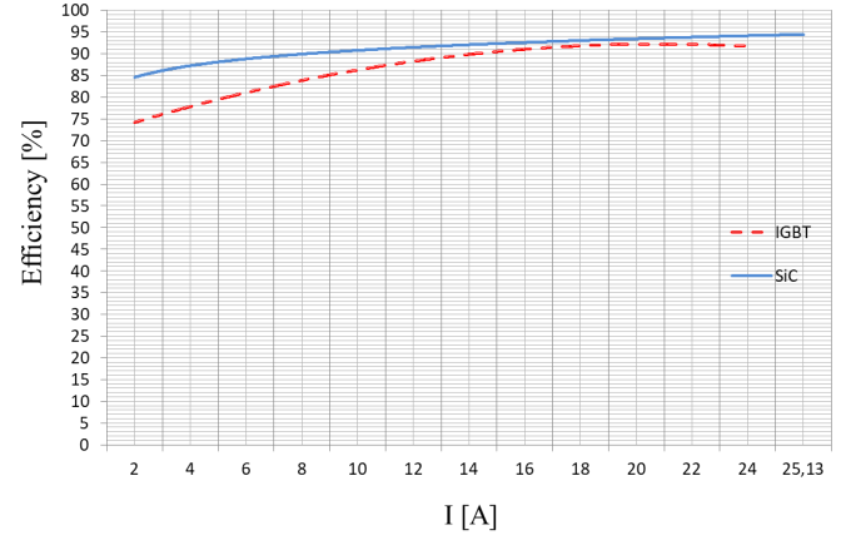

Fig. 8. Efficiency characteristics of Silicon IGBT and Silicon Carbide MOSFET for $10 \mathrm{kHz}$ switching frequency

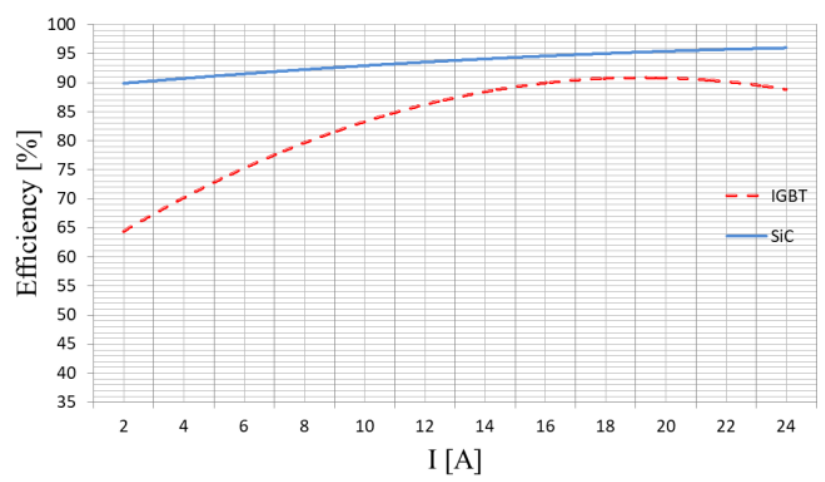

Fig. 9. Efficiency characteristics of Silicon IGBT and Silicon Carbide MOSFET for $20 \mathrm{kHz}$ switching frequency

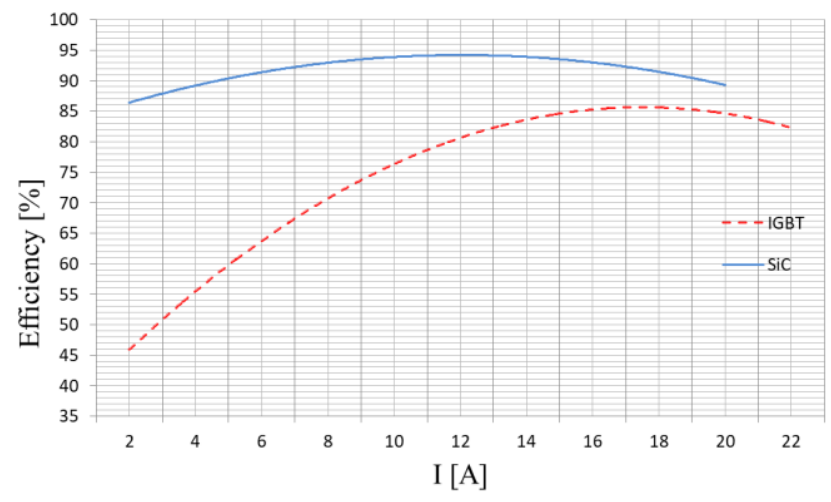

Fig. 10. Efficiency characteristics of Silicon IGBT and Silicon Carbide MOSFET for $40 \mathrm{kHz}$ switching frequency

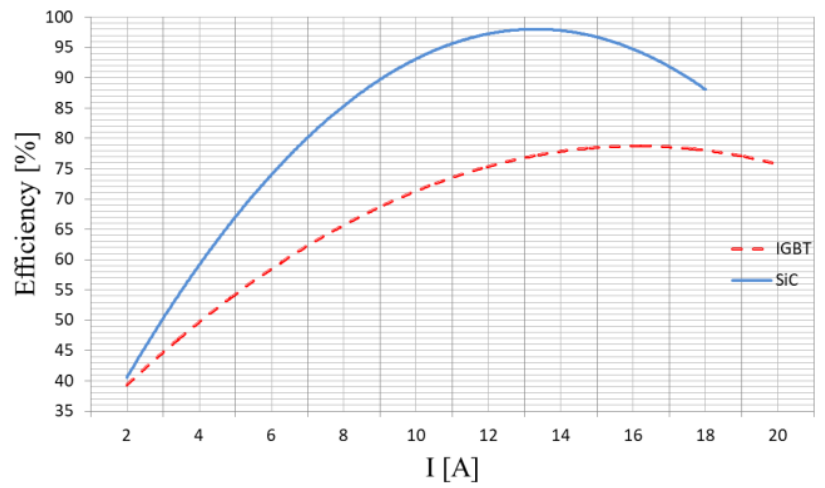

Fig. 11. Efficiency characteristics of Silicon IGBT and Silicon Carbide MOSFET for $60 \mathrm{kHz}$ switching frequency 


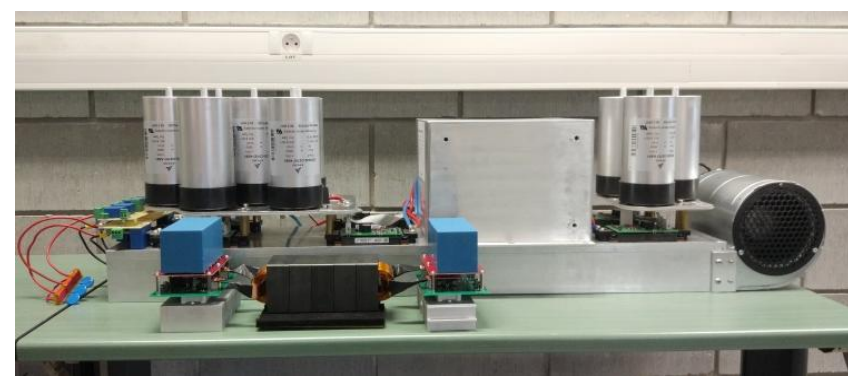

Fig. 12. Photograph of both the SiC MOSFET and Si IGBT converter-comparison of sizes

Thanks to the MOSFET properties and the Silicon Carbide technology it was possible to reduce the radiator size. The ability to switch transistors at $100 \mathrm{kHz}$ frequency allowed to significantly reduce the magnetic elements.

In summary, DC/DC converters made with silicon carbide semiconductor technology have a significant advantage over their IGBT silicon based counterparts. Their most significant features are small size, greater energy density and lower switching losses. This gives them a great potential and makes them a good alternative to IGBT converters in high-power systems.

\section{Bibliography}

[1] Barlik R., Nowak M., Grzejszczak P.: Power transfer analysis in a single phase dual active bridge. Bulletin of the Polish Academy of Sciences, Technical Sciences 61(4), 809-828.

[2] Dobrzański D.: Overview and characteristics of the EV fast charging connector systems. Maszyny Elektryczne: Zeszyty problemowe 3/2017, 91-96.

[3] Fatyga K., Mroczek B.: Charakterystyki pracy dwukierunkowej przetwornicy DC/DC do pojazdów elektrycznych i architektura jej komunikacji w systemie operatora sieci elektroenergetycznej. Maszyny Elektryczne: Zeszyty problemowe 3/2017 83-89.

[4] Inoue S., Akagi H.: A bi-directional isolated DC/DC converter as a core circuit of the next-generation medium-voltage power conversion system. 37th IEEE Power Electronics Specialists Conference - Jeju, 2006, 1-7.

[5] Zdanowski M., Rąbkowski J., Barlik R.: Design issues of the high-frequency interleaved DC/DC boost converter with Silicon Carbide MOSFETs. 16th European Conference on Power Electronics and Applications, 2014.

[6] Zhao B., Song Q., Liu W., Sun Y.: Overview of Dual-Active-Bridge Isolated Bidirectional DC-DC Converter for High-Frequency-Link Power-Conversion System. IEEE Transactions on Power Electronics 29(8), 4091-4106.

[7] Zieliński D., Tokovarov M.: Simulation and comparison of selected fast charge topologies. Informatyka, Automatyka, Pomiary w Gospodarce i Ochronie Środowiska - IAPGOŚ 3/2017, 23-28.

\section{M.Sc. Eng. Karol Fatyga}

e-mail: k.fatyga@pollub.pl

Graduated from the Faculty of Electrical Engineering and Computer Science of the Lublin University of Technology in 2016. Since then also employed as assistant lecturer at the university's Department of Electrical Drives and Machines. His research focuses on power converters, specifically on electric vehicle chargers and converters for coupling utility grid with energy storage. He is a member of the team working on NCBiR (National Centre for Research and Development) projects.

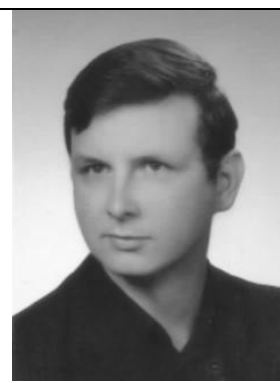

M.Sc. Eng. Lukasz Kwaśny

Graduated from the Faculty of Electrical Engineering and Computer Science of the Lublin University of Technology. Since 2016 employed at the Department of Electrical Drives and Machines there. His work revolves around simulation, design and assembly of power converters used in cooperation with renewable energy sources, and electric vehicle charging stations. $\mathrm{He}$ is a member of the team working on NCBiR (National Centre for Research and Development) projects.

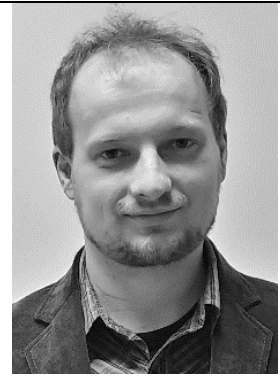

\section{B. Eng. Bartlomiej Stefańczak}

e-mail: bartlomiej.stefanczak@pollub.edu.pl

Undergraduate of the Lublin University of Technology with a Bachelor's degree in Engineering in Mechatronics. Currently pursuing his career by working for a Master's Degree at the Faculty of Electrical Engineering and Computer Science. He is employed in NCBiR (National Centre for Research and Development) funded projects undertaken at the university's Department of Electrical Drives and Machines. His interests combine power electronics and computer science. In his limited leisure time he is an active tennis player and swimmer. 